\title{
Inventory Information System (Case Study: Zahabi Hotel Jakarta)
}

\author{
Meinarini Catur Utami ${ }^{a^{*}}$, Elvi Fetrina ${ }^{b}$, Novita Rizkiah ${ }^{c}$ \\ a,b,c Department of Information System, Faculty of Science and Technology \\ Syarif Hidayatullah Islamic State University \\ J1. Ir. H. Juanda No. 95, Ciputat 15412 Jakarta \\ *Email: meinarini@uinjkt.ac.id
}

\begin{abstract}
Customer satisfaction is one of the important aspects for companies to be competitive in the market. Many companies especially those that are in the hotel industries, depend heavily on their ability to serve the need of their customers at the right time. Zahabi hotel, one of Sharia hotels in Jakarta, is having problems to keep up with their inventories of housekeeping supplies. The housekeeping division cannot cope up with the high numbers of occupancy of the hotel. Most of the times, its staffs could not fulfill the need of customer to have some extra on housekeeping supplies such as toiletries products, because the quantity of the products is very limited. Moreover, ordering the products to vendors will takes time. This ineffective inventory control caused the lack of housekeeping supplies in the warehouse that resulted in dissatisfaction of customers. To reduce the stock-out of inventory, the model of Economic Order Quantity (EOQ) and First in First Out (FIFO) as inentory method had been applied, and also use RAD for developing inventory system. This model would help the Zahabi's management to be able to provide service excellence and also at the same time to minimize the inventory holding and ordering costs.
\end{abstract}

Keywords: Inventory, RAD, FIFO, EOQ

\section{Introduction}

Inventory (inventory) is an important activity for the company, because it has a major influence on the size of corporate spending. In the absence of inventory, the company will be exposed to the risk that the company can not meet the needs and desires of consumers. This resulted in the company losing the opportunity to earn the profits that should be obtained from consumers [1].

Optimal inventory is a matter of concern for the operational process is not disrupted due to lack of inventory. By using the EOQ (Economic Order Quantity) model that can help in analyzing how many items must be ordered to minimize the cost of ordering and storage costs. And use FIFO (First In First Out) method to manage inventory flow [2].

Zahabi Hotel Jakarta is a company engaged in lodging services and as a meeting place that carries the concept of sharia, ranging from rooms that are designed with modern architecture equipped with worship equipment (sarong, mukena, prayer mat and Qur'an) in every His room, the absence of alcoholic beverages, both in rooms and in restaurants, and no non-mahrom guests in the same room.

As many guests come to stay and need more equipment, the housekeeper should provide the guests with the necessary needs, such as bath soap, towels, and so on. But sometimes at the warehouse (store) the hotel does not provide more equipment to minimize in the event of excess guests, as well as other equipment. The hotel only provides the amount of equipment in accordance with the estimated capacity of guests who come every day, then if the stock begins to thin out then re-purchased to the vendor, the purchase to the vendor will also take a week, so often run out of stock.

\section{Theory}

\section{A. Definition of Information System}

Information system is a system within an organization that reconcile the needs of daily transaction processing, support operations, managerial and strategic activities of an organization and provide certain outside parties with the necessary reports [3].

\section{B. Definition of Inventory}

Understanding Inventories by Freddy are materials or goods stored to fulfill a particular purpose, for example for use in the production or assembly process, for resale, or for parts of equipment or machinery [4]. Inventories may be raw materials, auxiliaries, in-process materials, finished goods, or parts. It can be argued that inventory is simply an idle source of funds because before inventory is used it means that the bonded funds in it can not be used for other purposes.

\section{Research Framework}

The stages of the research conducted in this study are as follows: 


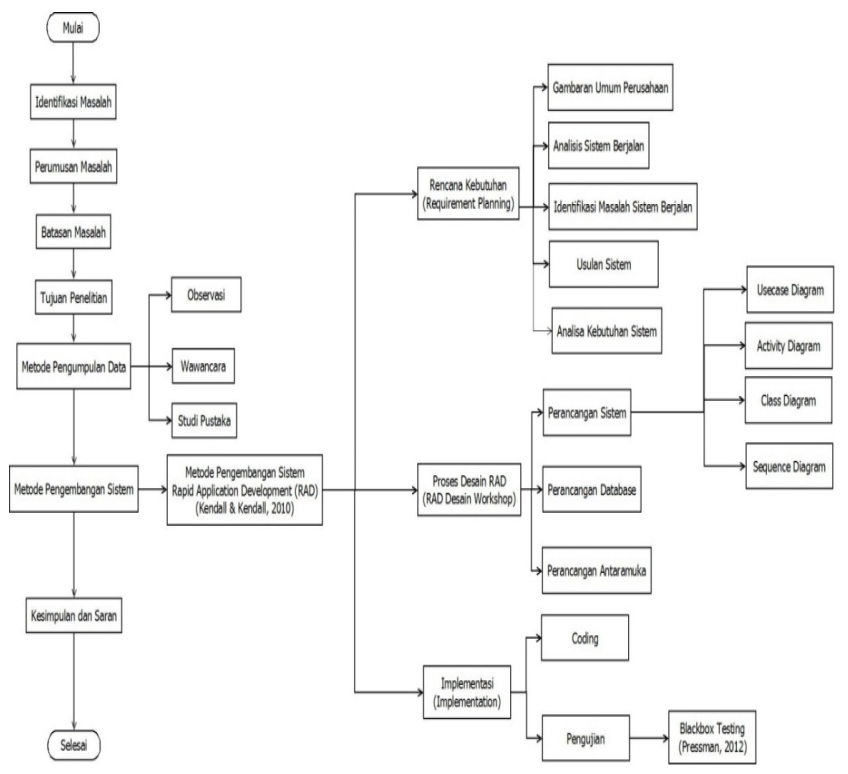

Figure 1. Research framework

\section{Discussion}

\section{A. Analysis of The Current System}

Here is a general overview of the business process of the inventory housekeeping, is as follows:

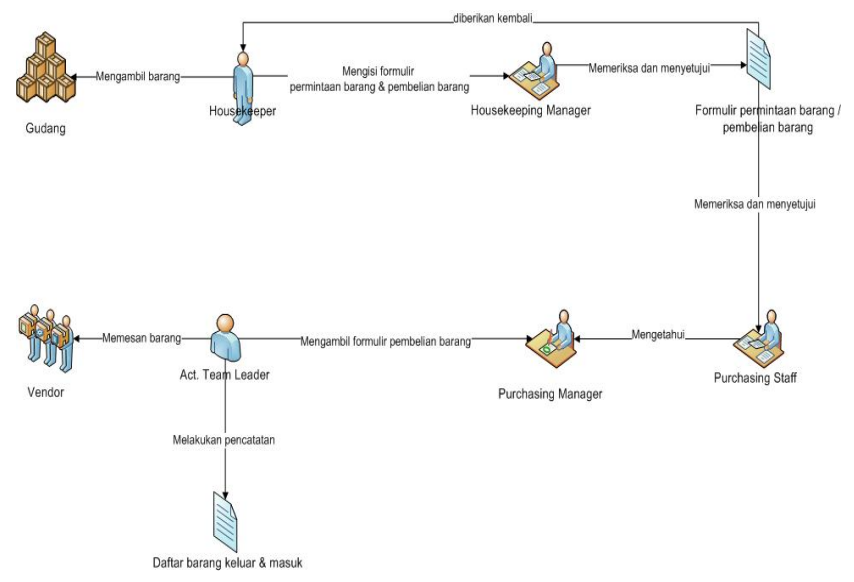

Figure 2. Rich picture of the current system

Based on the results of the analysis system that has been done, there are some weaknesses in the current system running, including as follows there is no digital storage in the database, data search process becomes more difficult and long, difficulties in distribution of reports.

\section{B. Analysis of The Proposed System}

From the results of analysis that has been described, then the system proposed by the author to overcome the problems on the running system is an information system Inventory Housekeeping at Zahabi Hotel Jakarta. This system is intended for the company especially the Housekeeping Division. The proposed system is internetbased as a medium of information and services that can be easily accessed anywhere and anytime.

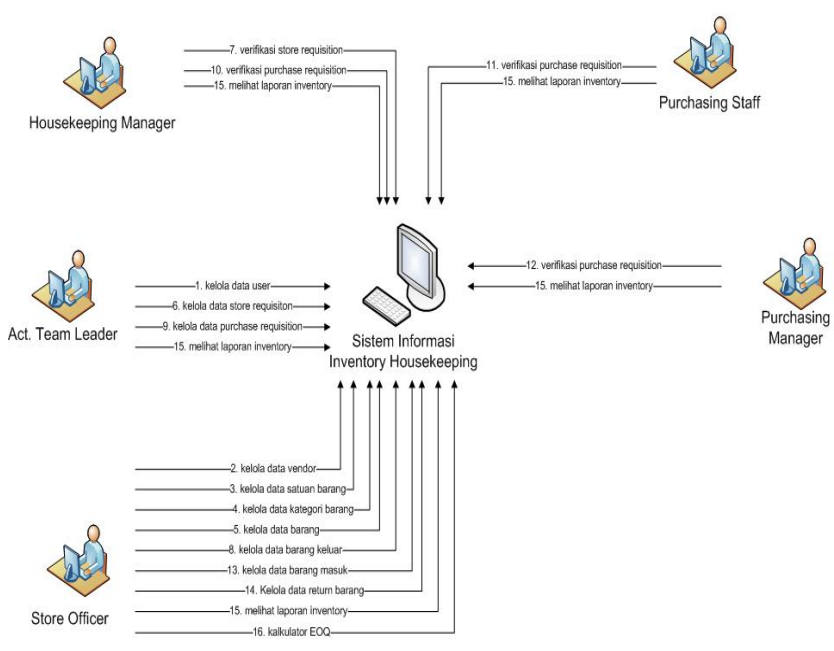

Figure 3. Rich picture of proposed system

\section{Design \\ 1. Use Case Diagram}

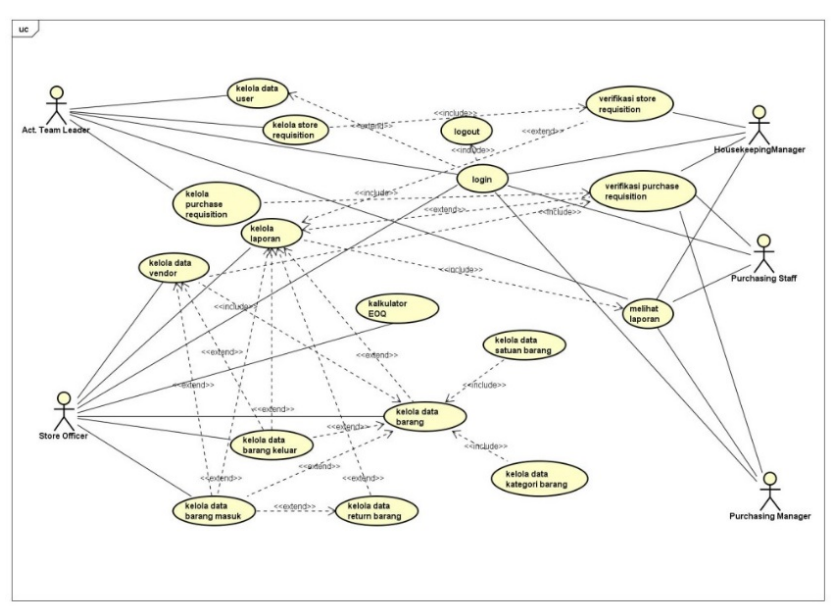

Figure 4. Use case diagram of inventory housekeeping

\section{Activity Diagram}

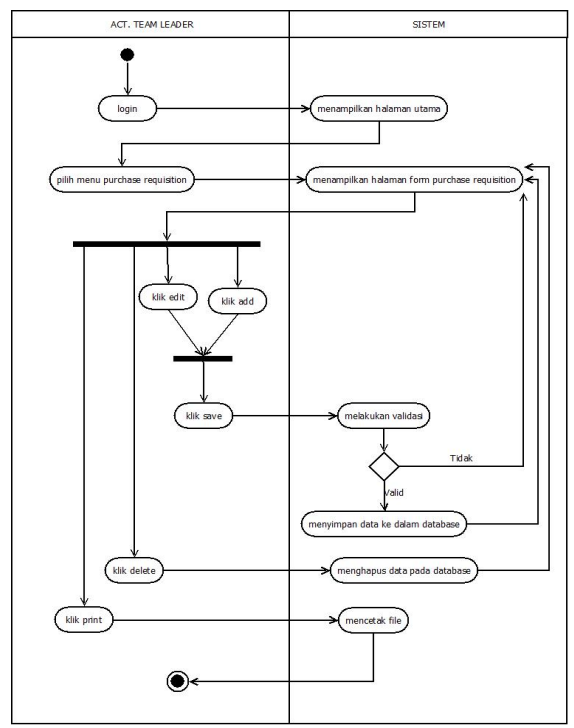


Figure 5. Activity diagram of purchase requisition

\section{Sequence Diagram}

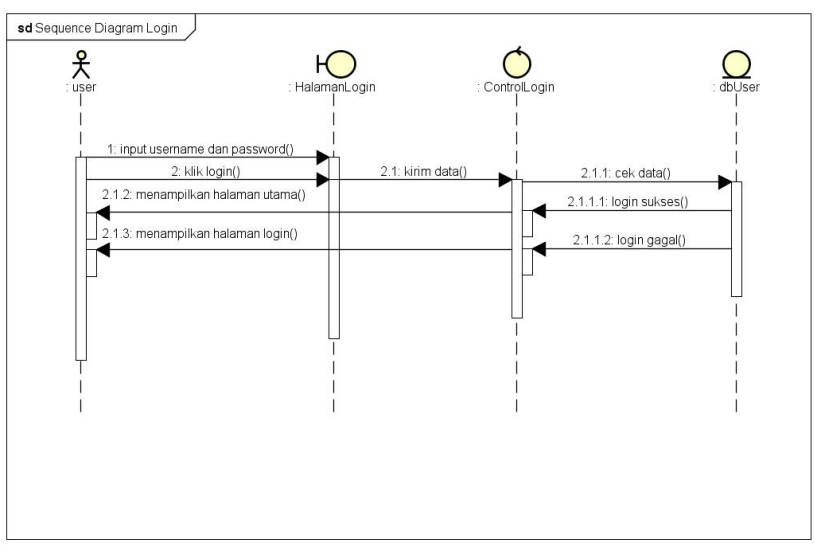

Figure 6. Sequence diagram of login

\section{Interface Design}

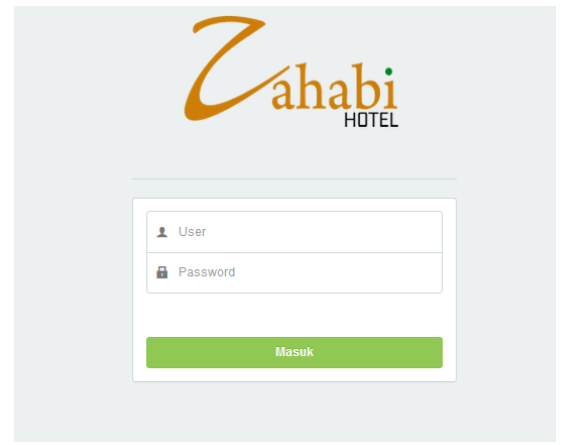

Figure 7. Interface of login

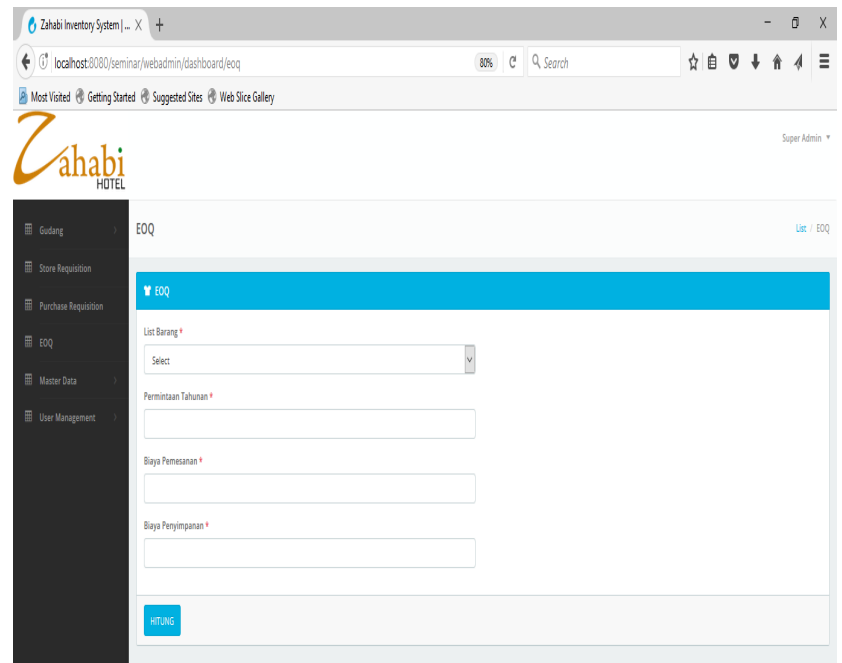

Figure 8. Interface of EOQ calculate

\section{Conclusion}

Based on previous descriptions and discussions, it may be concluded that:

1. Inventory information systems in the housekeeping department have been developed including the process of recording and management of inventory data, which uses a computerized system to facilitate the performance of employees involved in the process of inventory data management on the housekeeping (user friendly).

2. Inventory information system in housekeeping department has been developed including Purchase Requisition process and demand of goods to Store (Store Requisition), recording of vendor data, and reporting of stock that has been connected to database so that there is no data loss and data redundancy.

3. Computerized inventory information system housekeeping and well integrated in housekeeping division, made with PHP programming language with MySQL database with RAD system development method (Rapid Application Development) and UML (Unified Modeling Language) tools.

\section{References}

[1] Rusdiana, A. (2014). Manajemen Operasi. Bandung: Pustaka Setia.

[2] Assauri, S. (2008). Manajemen Produksi dan Operasi. Jakarta: LPFEUI.

[3] Jogiyanto, H. (2008). Metode Penelitian Sistem Informasi. Yogyakarta: Andi.

[4] Rusdiana, A. (2014). Manajemen Operasi. Bandung: Pustaka Setia. 